\title{
A SHABTI OF KING TAHARQA
}

\author{
Ahmed Sami Al-DEEB \\ Faculty of Arts, Ain Shams University, Egypt \\ drahmedsamy55@yahoo.com
}

\begin{abstract}
Shabtis are funerary objects of importance among the equipment of the deceased in ancient Egypt. Placed in tombs, their purpose was to work for the dead in the afterlife. This article deals with a recently restored shabti of one of the great kings of the Third Intermediate Period, king Taharqa of the $25^{\text {th }}$ Dynasty. It was among the king's collection of artefacts found inside his pyramid in Nuri in Lower Nubia. The shabti bears a version of the Sixth Chapter of the Book of the Dead. It asks the shabti to do work on behalf of his owner in the afterlife. The article compares this shabti and others belonging to Taharqa, as well as those of the king's successors, notably his grandson king Senkamanisken.
\end{abstract}

\section{KEYWORDS:}

Nuri; Taharqa; Book of Dead VI; Shabti; Senkamanisken; Third Intermediate Period.
تعتبر تماثيل الأوشابتي من القطع الأثرية الجنائزية

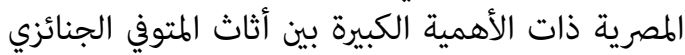

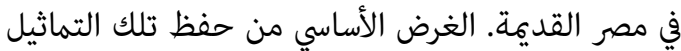

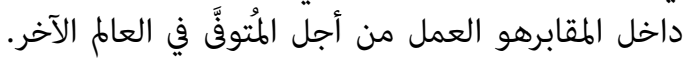

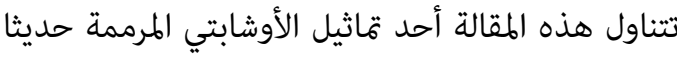
للملك طاهرقا، أحد ملوك عصر الإنتقال الثالث، الأسرة الثرة

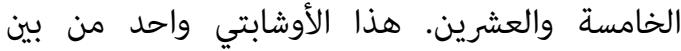

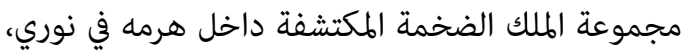

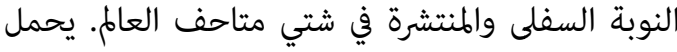

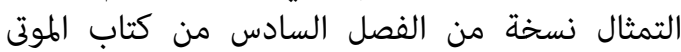

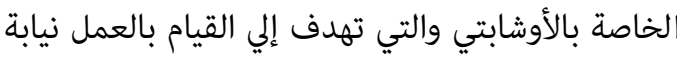

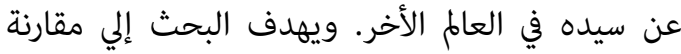

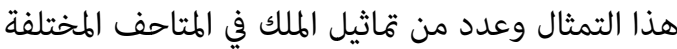

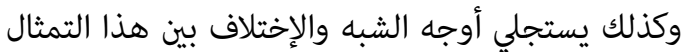

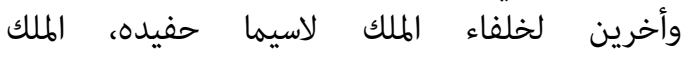

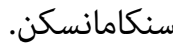

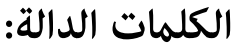
سنكامانسك, عصر الإنتقال الثالث.

\section{INTRODUCTION}

The shabti studied was recovered, among other antiquities, by the Egyptian authorities from criminals and tomb robbers practicing illicit smuggling. The statuette is now kept in the Dahshur antiquities magazine (hall 7, accession number 493). It is one of 
the king's shabtis found inside his pyramid at Nuri. A total of 1070 to 1122 shabtis has been suggested for his funerary equipment. ${ }^{1}$ Made of different materials, ${ }^{2}$ they are spread among different museums all over the world. This study compares this artefact to other shabtis of the king and of his successors.

\section{DESCRIPTION:}

Made in dolomite, ${ }^{3}$ this shabti measures H. $22.5 \mathrm{~cm}$, W. $8.5 \mathrm{~cm}$ and Th. $5 \mathrm{~cm}$. It represents the Nubian King Taharqa of the $25^{\text {th }}$ Dynasty. It was broken into three parts and was restored after its salvage by the Egyptian antiquities. A broken part near the end of the right foot subsists (Fig. 3). The king is represented wearing the h3theaddress which is a light and comfortable covering of the whole head, falling vertically behind the ears, and tied in a knot near the nape of the neck, in the form of a plait. The facial features are modelled as those of the old king. The face is not fully rounded with high cheekbones. He has medium-sized ears and a protruding mouth. The figure is shown with opposed hands, a uraeus on the forehead and a false beard, which is partially broken. In each hand, the figure holds a moulded hoe and the cord of a small bag slung over his shoulder. The hoe on the right has a narrow blade and the one on the left has a broad blade. ${ }^{4}$ The seed bags at the back are incised with diagonal crossed lines forming a diamond pattern (Fig. 4). There are ten incised horizontal lines of unframed hieroglyphic inscriptions on the front and the sides of the shabti; they do not continue on the back of the figure. They contain the formula for shabtis (Sixth Chapter of "The Book of the Dead"). It runs from right to left and reads $(\leftarrow):^{5}$

\footnotetext{
${ }^{1}$ Dunham and Aubert estimated 1070 shabtis for the king, Dunham, The Royal Cemeteries of Kush II, 10; Aubert and Aubert, Statuettes Égyptiennes Chaouabtis. 191. Another study mentioned a total number of at least 1122 and maybe higher as 275 fragments are preserved in BMFA collection, Haynes, "Ushabtis of King Taharqa", 31.

${ }^{2}$ For the different stone types and forms of Taharqa's shabtis, Haynes, "Ushabtis of King Taharqa" 3039; Haynes, Santini-Ritt, and Newman, Sculptural styles and stone types of Taharqa shawabtys, 515529.

${ }^{3}$ Among the stone shabti of Taharqa, a large number was initially described as granite and dull grey in colour. When the surface layers of the stone after long immersion in water were removed, the shabtis were really dark green. They were subsequently described as dolomite or ankerite; Dunham, Nuri II, 5 .

${ }^{4}$ During the New Kingdom, the concept of the shabti changed. They became more generic rather than personal representations, being regarded less as substitutes for the owner, and more as slaves to do his bidding. The number of the shabtis increased and this increase of shabtis per person reached its culmination during the Third Intermediate Period, with the establishment of a canonical organisation. Two types were clearly distinguished by their iconography; 'worker' shabtis followed the traditional form of the mummified body holding agricultural tools, while 'overseer' shabtis were depicted as alive, wearing daily dress, with a kilt and projecting apron; one arm was held at the side, the other flexed across the chest, the hand holding a whip to impose authority on the workers. So, the shabti under study, according to its iconography is one of the workers shabtis holding the two hoes. Schneider, Shabtis I, 319-323; Taylor, Death and the afterlife, 127-128.

${ }^{5}$ Schneider translated the full version VII in his study, Schneider, Shabtis I, 118-126.
} 

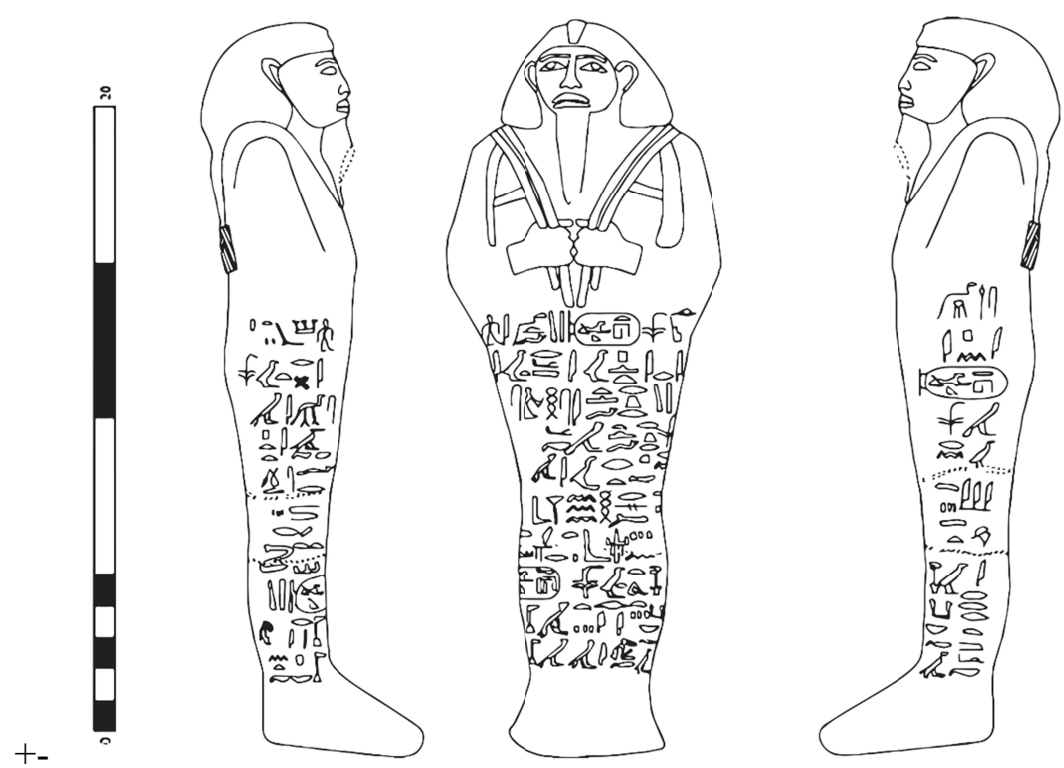

Pl. 1: Front and sides of shabti of Taharqa (Line Drawing by Mona Abady)

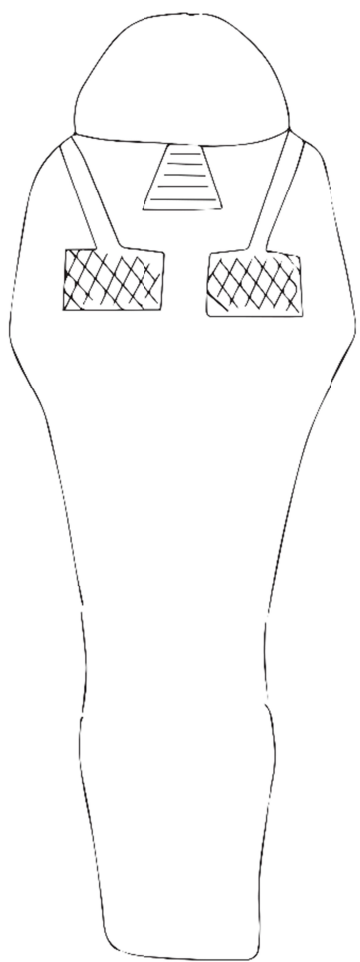

Pl. 2: Back side of the shabti (Line Drawing by Mona Abady) 


\section{THE SPELL}

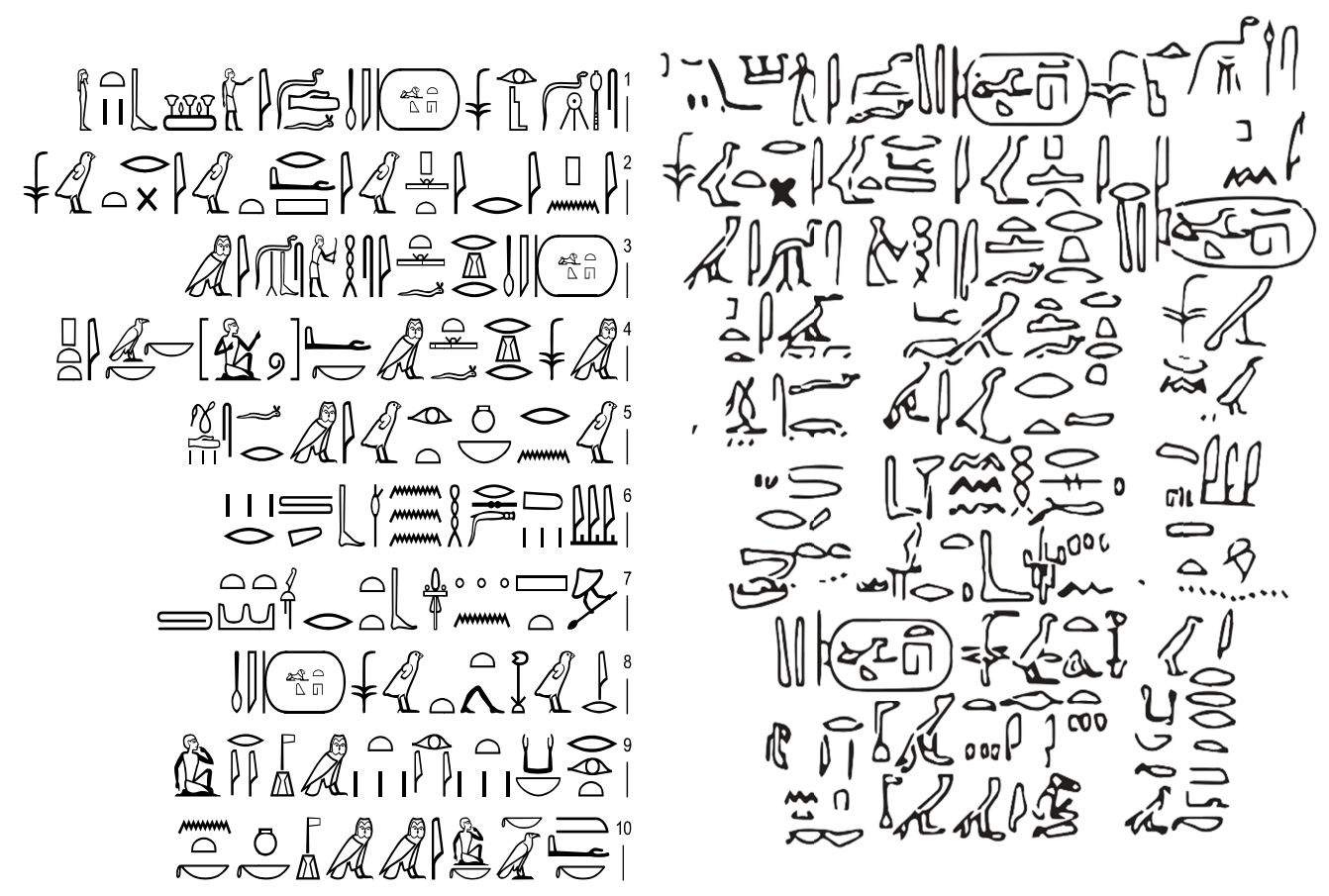

\section{TRANSELITERATION AND TRANSLATION}

(1) sḥ $\underline{d}$ Wir nsw (T3hrk) m3e-hrw dd.f i š3bty ${ }^{\mathrm{a}}$

The illuminated one, Osiris, the king Taharqa, justified, he says: Oh these shabtis!

(2) ipn ${ }^{\mathrm{b}}$ ir ip.tw ir `̌.tw ir hsb.tw ${ }^{\mathrm{c}} n s w$

If one counts, if one calls, if one reckons, king

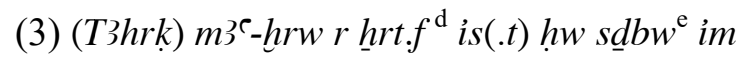

Taharqa, justified, at his duties, now indeed obstacles are imposed (implanted) there

(4) $m n s w r$ hrt.f $m k$ (wi) $)^{\mathrm{f}} k 3 . k^{\mathrm{g}} i p . t$

as a king at his duties, here (I am)! you shall say when you are counted

(5) $w r n w n b$ ir.twim.f r srwd

at any time on which one has to serve there (in it), to cultivate

(6) sht $r$ smhi $w \underline{d} b w r$

the fields, to irrigate Riverine lands, to

(7) hnt šy $n$ ỉsb(t)tr imntt $\underline{t} s-p \underline{h} r^{\mathrm{h}}$

transport by boat (to ship) sand from East to West, and vice-versa

(8) ir wh3.tw ${ }^{\mathrm{i}} n s w$ (T3hrk) m3e hrw

If one seeks (demands) King Taharqa, justified, 
(9) $r$ ir.t k3.wt nb.wt iryw.t m hrt-ntr iry.i

to do all the work done in the god's-land, I shall do it

(10) $m k$.(wi) k3.k im m hrt-ntr ink intk

Here I am! You shall say, there in this god's-land, (for) I'm you

\section{COMMENT}

a) $\breve{3} b t y$ is one of the different terms for Shabti, mostly used during this era. ${ }^{1}$

b) ipn is a plural masculine demonstrative adjective. ${ }^{2}$ Examples with the singular demonstrative pronouns $(p n, t n)$ are rare. ${ }^{3}$

c) $h s b . t w$ : "to reckon, to count", lit. "to break up (numbers)". ${ }^{4}$ On some shabtis from the Late Period, it is written in a different way $\quad 81]$ sather than what is seen here.

here. The sign $\bigcirc$ (Gardiner, Z 9) was used the same as $\times$ (Gardiner, Z 10) from the Old Kingdom. ${ }^{6}$

d) hrt: This term, meaning "task, duty" is part of the Task-clause of the shabti chapter. In the oldest version of the spell, the term hrt was singular, becoming plural "hrwt" during the Middle Kingdom, before being again a singular form during the New Kingdom. ${ }^{7}$ In the present version, it is again the singular form (hrt.i), with some examples for the plural $(\underline{h r w t . i)})^{8}$ Later on, it became the plural form (hrwt.f) with a different suffix pronoun $f$ instead of $i{ }^{9}$ On the other hand, the most common expression for duties was $k 3 t$ "work, labour", seen from Middle Kingdom till the Ptolemaic Period. ${ }^{10}$

e) $h w s \underline{d} b w i m^{11}$ : The principal meanings for $h w$ are "to beat, strike, smite, destroy, implant", ${ }^{12}$ while $s \underline{d} b$ has the meaning of "obstacle". ${ }^{13}$ This clause known as the Obstacle-clause is characteristics of the shabtis' spell. It is essential as it states the

\footnotetext{
${ }^{1}$ The shabtis can be called $̌ 3 b t y w, ~ s 3 b t y, ~ \varsigma 333 b t y$, and wšbty. Ouda, "Three Shabtis", 305, no. 19; Schneider, Shabtis I, 136-139; Taylor, Death and the afterlife, 114-116; Stewart, Egyptian shabtis, 13; Speleers, Les figurines funéraires, 87, 115-116; Spanel, "Notes on the Terminology", 249-253; Milde, 'Shabtis', 1-3, Table 1.

${ }^{2}$ Gardiner, EG, $\S 112$. It is also noted that the word $33 b t y$ was written in a singular form, followed by a masculine plural demonstrative pronoun ipn. From the Second Intermediate Period until the Late Period, it was customary to write the singular form $33 b t y$ with plural demonstrative pronouns (ipw, ipn, iptw, iptn), and the singular spellings occur mainly on Kushite specimens; Schneider, Shabtis I, 137.

${ }^{3}$ Ouda, "Three Shabtis", 305, no. 19. The shabtis of king Senkamanisken, from a Kushite dynasty, are an exception with the singular demonstrative pronoun. Hayes, "Translation and Study of Senkamanisken", 6-13; Amer, "An Ushabti of the King Senkamanisken", 35-47.

${ }^{4} \mathrm{~Wb}$ III, 166, 11-13, 167, 15 .

${ }^{5}$ For an example, Wojciechowska, "The ushabti of king Aspelta", 12-13.

${ }^{6}$ Check Gardiner Sign List, Z 9, Z 10, 538, and Aa2, 539.

${ }^{7}$ Schneider, Shabtis I, 142.

${ }^{8}$ Schneider, Shabtis I, 142; Bassir and Creasman, "Payeftjauemawyneith's shabti (UC 40093)", $164-$ 165 .

${ }^{9}$ For an example, Amer, "An Ushabti of the King Senkamanisken", 38.

${ }^{10}$ Schneider, Shabtis I, 142. For examples, Oostenrijk, "Individuality versus Uniformity", 58-61; Janes, Shabtis, 155, 159, 161, 174, 184, 188, 193, 196, 200.

${ }^{11}$ For this phrase, $h w j$ s $\underline{d} b$, see Gunn, "The Stela of Apries”, 227-228.

${ }^{12} \mathrm{~Wb}$ III, 46-47.

${ }^{13} \mathrm{~Wb}$ IV, 381.
}

- 101 - A Shabti of King Taharqa 
reason why the shabtis have to be brought into action. Sometimes the clause ends with the suffix pronoun (im.f, im.i, im.k), and others without, like in this instance. The participle ist, ist with the meaning of "indeed, now" introduces circumstantial sentences, such as the Obstacle-clause. "The idiomatic use of $h w i \underline{i} s \underline{b}$, "to obey" (instead of the usual "to implant an obstacle"), has been suggested by Heerma van Voss in a translation of the text on a shabti from a museum in Leeuwarden. ${ }^{2}$

f) $m k$ (wi): "now see, behold". In Kushite and Theban contemporary shabtis, dating to the $25^{\text {th }}$ and early $26^{\text {th }}$ Dynasties, the sentence was $m k s w(s y)$ here he is . hqwever, on the whole collection of Taharqa, it is $m k$ (wi) "here I am".

g) $k$ 3: "to say". It is here in an irregular form without the determinative of a man putting his finger to his mouth an ${ }^{4}$ The suffix pronoun $k$ is on occasions replaced with the plural form $t n$ or $t n^{5}$

h) $\underline{h n t} \check{s}^{\ulcorner} y^{6} \rightarrow t s-p h r$ : "transport by boat (to ship) sand from East to West, and viceversa". 7 This is one of the most important clauses connected with the afterlife, as the plots of land in the fields of Iarw are separated by sand. In the Book of Amduat, the division of land plays an important role, as it is the main theme of the second hour. The sun-god makes his journey over a broad stream. On the shores of this river, the field plots of the Akhu are located. These fields are measured and divided by sand. ${ }^{8}$ The transportation of sand in the irrigation of the Iarw fields was difficult and the most common activity one could imagine being done there. The interpretation of "sand" remains challenging. 9 " The sand here, $\check{s} y$, ${ }^{10}$ refers not only to the desert sand, but also to the sandy silt deposited by the inundation waters; after the withdrawal of the water of the flood, this residue had to be spread over the cultivation areas, acting as a fertiliser. ${ }^{11}$ It might also be sand from the desert blown over the arable fields that should be removed, ${ }^{12}$ or material for building dykes around the fields, or fertiliser ${ }^{13}$ comparable to the $s e b a k h^{14}$ used by present-day fellahin "farmers".

Regarding the orientation, two terms imntt and i3btt, respectively West and East, are important to note. Both words are likely to be synonymous to the Eastern and Western shores of the Nile, but also two sides of the agricultural land, thus the notions of right

\footnotetext{
${ }^{1}$ Schneider, Shabtis. I, 145; Gardiner, EG $§ 119.2,3$, and $\S 247$.

${ }^{2}$ Heerma van Voss, Oud Egypte in het Princessehof, 4; Milde, "Shabtis", 7.

${ }^{3}$ The shabtis of the Napatan king Senkamanisken are evidence for this $m k s w$ expression. Schneider, Shabtis I, 119, 145-146; Amer, "An Ushabti of the King Senkamanisken", 41; Wojciechowska, "The ushabti of king Aspelta", 11-14.

${ }^{4}$ For examples from the same era for the word $k 3$ without the determinative of the man putting his

finger in his mouth , Islam I. Amer, "An Ushabti of the King Senkamanisken", 38-42; Glenn, Shabtis, XIX, 186.

${ }^{5}$ For examples from the same era, Shahen, "TIP / LP ushabtis in the Egyptian collection", 34, 43-44; Bassir and Creasman, "Payeftjauemawyneith's shabti (UC 40093)", 164-165; Janes, Shabtis, 153, 155, 157, 159, 161, 174, 188, 196, 200, 212.

${ }^{6}$ For details about sand transportation, Heerma van Voss, "On the Meaning of the Shipping of Sand".

${ }^{7} \mathrm{~Wb} \mathrm{~V} 404$.

${ }^{8}$ Hornung, Amduat I, 43.

${ }^{9}$ Heerma van Voss, "De sjawabti's en het zandmysterie", 53-57.

${ }^{10} \mathrm{~Wb}$ IV, 219

${ }^{11}$ Schneider, Shabtis I, 57-59.

${ }^{12}$ Petrie, Shabtis, 10

${ }^{13}$ Hornung, Das Totenbuch der Ägypter, 48.

${ }^{14}$ Schneider, Shabtis I, 58; Milde, Shabtis, 7.
} 
and left. ${ }^{1}$ The notion $t s-p h r$ "vice versa", is added to express completeness. The direction of the sand transportation here is a matter of debate as the Middle and New Kingdom versions nearly always have a single transport direction (without $t s-p h \underline{h}$ ). i3btt or imntt could also be mentioned first with no consideration for the sequence. ${ }^{2}$ In In other cases, the notion of transporting to the opposite side was not mentioned at all "to transport by boat the sand to the west or to the east". In other words, this clause became one of the characteristics from the Third Intermediate Period onwards. Sometimes, this clause was repeated without the notion $t s-p h r$ but with the repetition of the transportation direction. ${ }^{3}$ This feature was not known before the $25^{\text {th }}$ Dynasty. ${ }^{4}$ Dynasty. ${ }^{4}$ The orientation of the sand transportation in the shabti studied is East-West.

West.

i) ir wh3.tw": "if one seeks" is one of the characteristics of this version VIIB. This clause is already known from texts of shabti dating to the New Kingdom. Since it is found on most shabtis of king Taharqa, it has been called Taharqa-variant. ${ }^{6}$ It is followed by a long interval where the name of the deceased was placed. This clause was found on shabtis from the time of Ramesses IV, but during the Third Intermediate and the Late Periods, it became a major part of the spell. It helps in dating shabtis. ${ }^{7}$

j) ink intk: ("for" I am you). ${ }^{8}$ This sentence, said by the owner of the shabti, in addition to the previous notion (ir wh3.tw), became the main characteristics of Taharqa's shabtis. Both variants, ir wh3.tw and ink intk, are used in dating different shabtis as they are exclusive to Taharqa's shabtis. ${ }^{9}$

\section{DISCUSSION}

Despite the illegal provenance of this shabti, it is likely to have originated from the province of Nuri in Sudan. Taharqa built his pyramid on the site of Nuri, one of the largest in Kush. ${ }^{10}$ This shabti may belong to a series of at least 1122 "answerers" found inside the king's pyramid. ${ }^{11}$ Taharqa was the first Kushite ruler to use hard stone for his shabtis, as well as all his funerary figures, and even the first king to use hard stones shabtis since the New Kingdom. ${ }^{12}$ The shabtis of Taharqa exemplify the desire of these Kushite kings to draw inspiration from the great ages of Egypt's past. They are of exceptionally large size, and are carved from a variety of stones (granite,

\footnotetext{
${ }^{1}$ Schneider, Shabtis I, 59.

${ }^{2}$ Schneider, Shabtis I, 60.

${ }^{3}$ Schneider, Shabtis I, 150-152. For more details about $\underline{t} s-p \underline{h r}$, Westendorf, "Der Rezitationsvermerk ts-phr , in: Firchow, 383-402.

${ }^{4}$ Schneider, Shabti I, 60; Welc, "A fragment of a Shabti", 97.

${ }^{5} \mathrm{~Wb}$ I, 353, 14-16.

${ }^{6}$ Schneider, Shabtis I, 119.

${ }^{7}$ Piankoff, "Deux Variantes du Chapitre VI", 169-170.

${ }^{8}$ Gardiner, $E G, \S 114$, for more information about ink intk; Piankoff, "Deux Variantes du Chapitre VI", VI", 169-170; Birch, "On Sepulchral figures", 21. Both variants are also found on two shabtis for Taharqa excavated by Reisner in 1920 in Nuri and now preserved in Room 35 in the Egyptian Museum, JE 46506 and JE 46509.

${ }^{9}$ Welc, "A fragment of a Shabti", 97.

${ }^{10}$ It was excavated by the Harvard University-MFA expedition, under George Reisner in 1916-1918.

${ }^{11}$ Haynes, "Ushabtis of King Taharqa", 31.

12 Haynes, "Ushabtis of King Taharqa", 37, note 3; Aubert and Aubert, Statuettes Égyptiennes Chaouabtis, 192, 204.
}

-103 - A Shabti of King Taharqa 
calcite and ankerite). In this, and in their rugged, strongly-marked sculptural qualities, the figures recall the large stone shabtis of the Middle and New Kingdoms. ${ }^{1}$

During the $25^{\text {th }}$ Dynasty, there was a nostalgic return to artistic forms and styles of the past, particularly forms from the Middle Kingdom. ${ }^{2}$ The use of stone for royal statuary and the sculptural style are the best examples of this tendency. Indeed, ushabti figurines of the pharaoh with the somewhat rough carving of the body, the facial features and the use of obsolete versions of inscribed text, all reflect the influence of models that date from the Middle and New Kingdoms.

It is important to compare this piece to other shabtis for Taharqa and successive kings from different museums. The collection of the Egyptian Museum in addition to those of Boston Museum of Fine Arts (BMFA), Ontario Museum, Brooklyn Museum, appear to be the best examples to do such comparison.

The Egyptian Museum houses a large collection of the king's shabtis of various materials, sizes, and features. The first shabti (Fig. 10) is made of sandstone and differs from all of the other of the Egyptian Museum due to its large size $(\mathrm{H} .35 \mathrm{~cm})$. It represents a middle-aged king wearing the $h 3 t$ and a uraeus on the forehead. He is shown with a rounded face, full cheeks, thin lips, big ears and long thin false beard. It bears incised texts of 10 horizontal lines of Chapter Six of the Book of the Dead. The second shabti (Fig. 11) is made of serpentine in a bad state of preservation, and seems very rough. It represents the king wearing the $h 3 t$ with the uraeus on the forehead and with a short beard roughly attached to his chin. He is shown middle-aged holding two hoes. The incised text runs in ten horizontal lines in a rough manner. The third one (Fig. 12) in serpentine is in a perfect state of preservation. The king wears the h3t and is shown in middle age with an uraeus on the forehead. He has a rounded face and full cheeks, well modelled ears and a long false beard. He is shown with free hands under the garment and is holding two moulded hoes. It differs from the studied shabti as the text comprises nine horizontal lines instead of ten. The fourth shabti (Fig. 13) also made of serpentine is different, wearing the nemes and holding the flail and the crook. He is shown with full cheeks, fleshy lips, big ears and a short false beard. Like the shabti of Fig. 12, the incised text runs in nine horizontal lines in a very good manner.

The biggest collection of the Taharqa's shabtis is in the Boston Museum of Fine Arts (Fig. 6) with no less than 645 figurines of different stones. ${ }^{3}$ Some years ago, Joyce Haynes published a study on the shabtis of Taharqa at the Boston Museum. ${ }^{4}$ They differ in size, ${ }^{5}$ features and stone types. ${ }^{6}$ Like the shabti under study, some are wearing the $h 3 t$-headdress, while others wear the nemes-headdress. ${ }^{7}$ All shabtis of the collection are represented with one uraeus on the forehead. The neck is shorter and sunk in the body in the shabtis with h3t-headdress unlike the longer necks seen on

\footnotetext{
${ }^{1}$ Taylor and Strudwick, "Mummies", 230-231; Aubert and Aubert, Statuettes Égyptiennes Chaouabtis, 204.

${ }^{2}$ Stewart, Egyptian shabtis, 28; Taylor and Strudwick, "Mummies", 230; Aubert and Aubert, Statuettes Égyptiennes Chaouabtis. 192.

${ }^{3}$ Haynes, "Ushabtis of King Taharqa", 33.

${ }^{4}$ Haynes, "Ushabtis of King Taharqa", 30-39.

${ }^{5}$ The BMFA group breaks down into four sizes: small, 17 to $22.9 \mathrm{~cm}$; medium, 23 to $29.9 \mathrm{~cm}$; large 30 30 to $39.9 \mathrm{~cm}$, and colossal, 40 to $52 \mathrm{~cm}$; Haynes, "Ushabtis of King Taharqa", 35.

${ }^{6}$ Haynes listed four stone types for the shabtis at Boston Museum, grey serpentinite, red-brown serpentinite, travertine (Egyptian alabaster), and green magnesite; Haynes, "Ushabtis of King Taharqa", 32.

${ }^{7}$ Haynes, "Ushabtis of King Taharqa", 33, 36.
} 
those with the nemes-headdress. ${ }^{1}$ The majority has old-age facial features, while fewer show the king middle aged. They have Kushite appearance, with big ears and lips. The ears are not protruding like the shabtis with the nemes-headdress. Some have average shoulders, while others have narrow ones. ${ }^{2}$ On the studied shabti, the nostrils are sculpted, but others are shown without. ${ }^{3}$ Like the majority of the king's shabtis, the the one under study is represented with sleeved opposed-hands in high relief, rather than crossed arms. ${ }^{4}$ It is broad at the elbows with a deep chest from front to back unlike some other shabtis, even those with the h3t-headdress. ${ }^{5}$ The king is shown holding two moulded hoes, common in shabtis with the $h 3 t$-headdress, unlike the ones with the nemes-headdress which are shown with the crook and the flail. ${ }^{6}$ The absence of footmarks on the bottom of this shabti is different from the others. ${ }^{7}$

At the Royal Ontario Museum (Fig. 5), a shabti for the king in serpentine is represented wearing the $h 3 t$ headdress but shown in middle age with a rounded face, full cheeks and thin lips. His opposed arms are holding the two hoes, with seed bags slung on his back. The same ten horizontal lines of Chapter Six of the Book of the Dead adorn the body. The Brooklyn Museum also holds another collection of Taharqa's shabtis. They are made of different materials like calcite and ankerite (Fig. $7,8,9)$. They look somewhat similar to the shabti under study. They are all of a middle-aged king wearing the $h 3 t$-headdress with a uraeus on the forehead. They all have a rounded face, full cheeks and thin lips. The three shabtis are shown with opposed hands holding the moulded hoes. Only the calcite one has ten horizontal lines of incised text while the two of ankerite have nine.

The reliance on older models of shabtis, Middle and New Kingdoms, is also apparent in the shabti spell, Chapter Six of the Book of the Dead, ${ }^{8}$ across the king's body. The text is based on much earlier versions, with unusually full wording in place of the abbreviated texts that had been in fashion during the Third Intermediate Period. ${ }^{9}$ Schneider divided Chapter Six of the Book of the Dead into many versions. This text is version VIIB (standard for the Third Intermediate and Late Periods, Summons III). ${ }^{10}$ This version was even named after the king's name "Taharqa's version" or "Taharqa's variants". ${ }^{11}$

The classical formula inscribed on shabtis from the early beginning usually ends with the sand clause $r \underline{h n t}$ šy imntt ỉbtt ts phr mk wi k3.tn which is usually translated "to transport by boat the sand of the east to the west and vice-versa; 'here I am,' you shall

\footnotetext{
${ }^{1}$ Haynes, "Ushabtis of King Taharqa", 36.

${ }^{2}$ Haynes, "Ushabtis of King Taharqa", 35.

${ }^{3}$ Haynes, "Ushabtis of King Taharqa", 34.

${ }^{4}$ For different hand positions of Taharqa shabtis, Haynes, "Ushabtis of King Taharqa", 33-39; for the hand position in general, Janes, Shabtis, 243.

${ }^{5}$ Haynes, "Ushabtis of King Taharqa", 33.

${ }^{6}$ Haynes, "Ushabtis of King Taharqa", 36.

${ }^{7}$ Footmarks are observable on the bottom of the foot on fifty-eight of the Taharqa shabtis. These marks marks are a lightly incised sign or signs placed near the centre bottom of the foot, oriented with the top towards the toe end. Most signs appear to be based on Egyptian hieroglyphs and their variants. They were found on about two percent of the total, indicating that their use was not common. Dunham published fourteen footmarks, but twenty-five variants have been identified, for a total of thirty unique marks. For the different footmark signs, Haynes, "Ushabtis of King Taharqa", 35, 38-9.

${ }^{8}$ Piankoff, "Deux Variantes du Chapitre VI", 170.

${ }^{9}$ Taylor and Strudwick, "Mummies", 230.

${ }^{10}$ Schneider, Shabtis I, 120.

${ }^{11}$ Schneider, Shabtis I, 123, 154; Janes, Shabtis, 248.
}

- 105 - A Shabti of King Taharqa 
say". They all have the classical sequence, Osiris $s h d$-notion, obstacle-clause, sandclause " $t s-p h r$, in addition to the two variants specific to Taharqa's shabtis " $i r w h 3-$ $t w$ " and "ink intk". ${ }^{2}$ Taharqa's shabtis are indeed characterised by the two notions ir wh3.tw "if one seeks" and ink intk "(for) I am you" since both are only found on this king's shabtis. The shabtis from the Third Intermediate and Late Periods end at the sand clause, without these variants. ${ }^{3}$ Similarities to Egyptian or Kushite sculptures suggest that the shabtis of Taharqa may have been worked by local sculptors at or near the Egyptian or Kushite quarries. Furthermore, the stylistic differences associated with the stone types may ultimately be related to the location of their quarries. The different artistic styles and stone types suggest several individual workshops in Egypt and in Nubia. Each workshop would have had its own head sculptor and workforce producing a group of shabti figures unique in material, size and artistic style. ${ }^{4}$

As for the comparison between the king's shabtis and any of his successors, those of his grandson king Senkamanisken appear to be the best examples. For the artistic style, many features of these shabtis distinguish them from others produced in Egypt, such as the two uraei borrowed from the New Kingdom, ${ }^{5}$ indicating Kushite royalty, and textual peculiarities. ${ }^{6}$ The majority of Senkamanisken's shabtis wear the nemesheaddress, sometimes lappet-wig, ${ }^{7}$ unlike the shabtis of Taharqa with various wigs, like the $h 3 t$-headdress. Taharqa and Senkamanisken's shabtis share the same hand positions as in majority the arms are crossed, and rarely in an opposed hands-manner. ${ }^{8}$

manner. ${ }^{8}$

\section{CONCLUSION}

This shabti is a good example of king Taharqa's funerary figurines. It is well preserved and bears a good version of Chapter Six of the Book of the Dead consecrated to shabtis. The version significantly differs from texts seen on shabtis of his predecessors and successors, being exclusive to king Taharqa. The spell is type VIIB according to Schneider's classification. This shabti has extra variants exclusive for king Taharqa and even related to his name "Taharqa Version" or "Taharqa Variant". The two main clauses for the king are the "Obstacle-Clause" and the "SandClause". Taharqa's shabtis are characterised by the two expressions ir wh3.tw "if one seeks" and ink intk "(for) I am you", both found on all shabtis.

\footnotetext{
${ }^{1}$ Quirke, Going out by daylight, 21-22; Allen, The Book of the Dead, 8; Von Dassow, ed., The Egyptian Book of the Dead, 101 [6]; Lapp, The Papyrus of Nu (BM EA 10477), 73 [6], pl. 62; Hornung, Das Totenbuch der Ägypter, 47-48, 417; Janes, Shabtis, xix; Stewart, Egyptian shabtis, 48.

${ }^{2}$ Schneider, Shabtis I, 119, 123.

${ }^{3}$ For examples from the same era, Shahen, "TIP / LP ushabtis in the Egyptian collection", 34, 43-4; Bassir and Creasman "Payeftjauemawyneith's shabti (UC 40093)", 164-165; Janes, Shabtis, 153, 155 , 157, 159, 161, 174, 188, 196, 200, 212; Wojciechowska, "The ushabti of king Aspelta", 11-14; Stewart, Egyptian shabtis, 48.

${ }^{4}$ Haynes, "Ushabtis of King Taharqa", 36-37.

${ }^{5}$ Aubert and Aubert, Statuettes Égyptiennes Chaouabtis, 192.

${ }^{6}$ For the features of the shabtis of king Senkamanisken, Haynes and Leprohon, "Napatan Shawabtis", 18-32; for examples, Royal Ontario Museum, accession no. 926.15.1, and Brooklyn Museum, accession no. 39.5

${ }^{7}$ For an example, Amer, "An Ushabti of the King Senkamanisken", 35-47.

${ }^{8}$ Stewart, Egyptian shabtis, 28-29.
} 


\section{BIBLIOGRAPHY}

1. Allen, Th., The Egyptian Book of Dead Documents in the Oriental Institute Museum at the university of Chicago, Chicago, (1960).

2. Amer, Islam., "An Ushabti of the King Senkamanisken", SHEDET 5, (2018), 35-47.

3. Aubert (Jacques-F.) and Aubert (Liliane), Statuettes Égyptiennes Chaouabtis, Paris, (1974).

4. Bassir, H\& Creasman, P., "Payeftjauemawyneith's Shabti (UC 40093) and another from Nebesheh", Journal of the American Research Center in Egypt 50 (2014), 161-169.

5. Dunham, D., The Royal Cemeteries of Kush, vol. II, Nuri, Boston, (1955).

6. Gunn, B., "The Stela of Apries at Mitrahîna," ASAE 27, (1927), 211-237.

7. Hayes, Evelyn., "A Study of the Royal Ontario Museum's Shabti of Senkamanisken", Undergraduate Journal of Near and Middle Eastern Civilizations 11, (2018), 6-13

8. Haynes, J; Santini-Ritt, M; Newman, R., "Sculptural styles and stone types of Taharqa shawabtys", in Zach (Michael H.) (ed.), The Kushite world: Proceedings of the $11^{\text {th }}$ international conference for Meroitic studies, Vienna, 1-4 September, (2008), 515-529.

9. --------., "Ushabtis of King Taharqa at the Museum of Fine Arts, Boston" KMT 20, (2009), no. 3, 30-39.

10. Haynes, J and Leprohon, R., "Napatan Shawabtis in the Royal Ontario Museum." Journal of the Society for the Study of Egyptian Antiquities 17, (1987), 18-32.

11. Heerma van Voss, M., "De sjawabti's en het zandmysterie", Phoenix 9, (1963), 53-57.

12. __ "On the Meaning of the Shipping of Sand by the Shawabtis", in: Proceedings of the twenty-sixth international Congress of Orientalists 2, New Delhi, (1968).

13. , Oud Egypte in het Princessehof. Leeuwarden: Museum het Princessehof, 1987.

14. Hornung, E., Das Amduat I, Ägyptologische Abhandlungen 7, Wiesbaden, (1963).

15. _ Das Totenbuch der Ägypter. Zurich and Munich, Artemis, (1979).

16. Janes, G., Shabtis: a private view. Ancient Egyptian funerary statuettes in European private collections, Cybèle, (2002).

17. Milde, H., "Shabtis", in Wendrich (Willeke) (ed.), UCLA Encyclopedia of Egyptology (2012), Los Angeles, 1-15.

18. Oostenrijk, J., "Individuality versus Uniformity: Twenty-Sixth Dynasty Shabti Groups from Saqqara”, Saqqara Newsletter 10, (2012), 58-61.

19. Ouda, A., "Three Shabtis of the Vizier Paser (UC39724-39726)", JARCE 52, (2016), 303320.

20. Piankoff, A., "Deux Variantes du Chapitre VI du 'Livre des Morts' Sur les Ouchabtis", ASAE 49, (1949), 169-170.

21. Quirke, S., Going out in daylight- prt $m$ hrw, the Ancient Egyptian Book of the Dead, Translation Sources, Meanings, GHP Egyptology 20, London, (2013).

22. Reeves, N., "An Unpublished Royal Shabti of the $26^{\text {th }}$ Dynasty", GM 154, (1997), 93-97.

23. Schneider, H., Shabtis. An Introduction to the history of Ancient Egyptian funerary statuettes, with A Catalogue of the collection of Shabtis in the National Museum of Antiquities at Leiden, vol. I, Leiden, (1977).

24. Shahen, A., "TIP / LP ushabtis in the Egyptian collection of the University Museum, Philadelphia, U.S.A", The Journal of the Faculty of Archaeology 7, (1996), 27-51.

25. Spanel, D., "Notes on the Terminology for Funerary Figurines", SAK 13, (1986), 249-253.

26. Stewart, H., Egyptian shabtis, London: Shire Egyptology, (1995).

27. Taylor, J., Death and the afterlife in ancient Egypt, London: British Museum Press, (2001).

28. and Strudwick, N., "Mummies: Death and the Afterlife in Ancient Egypt", Treasures from The British Museum, Santa Ana and London, (2005).

29. Welc, F., "A fragment of a shabti from Thebes", GM 145, (1995), 95-99.

30. Westendorf, W., "Der Rezitationsvermerk tss-phhr," in Firchow, O(ed.), Ägyptologische Studien Berlin, (1955), 383-402.

31. Wojciechowska, A., "The ushabti of king Aspelta". Aegyptus 90, (2010), 11-14.

- 107 - A Shabti of King Taharqa 


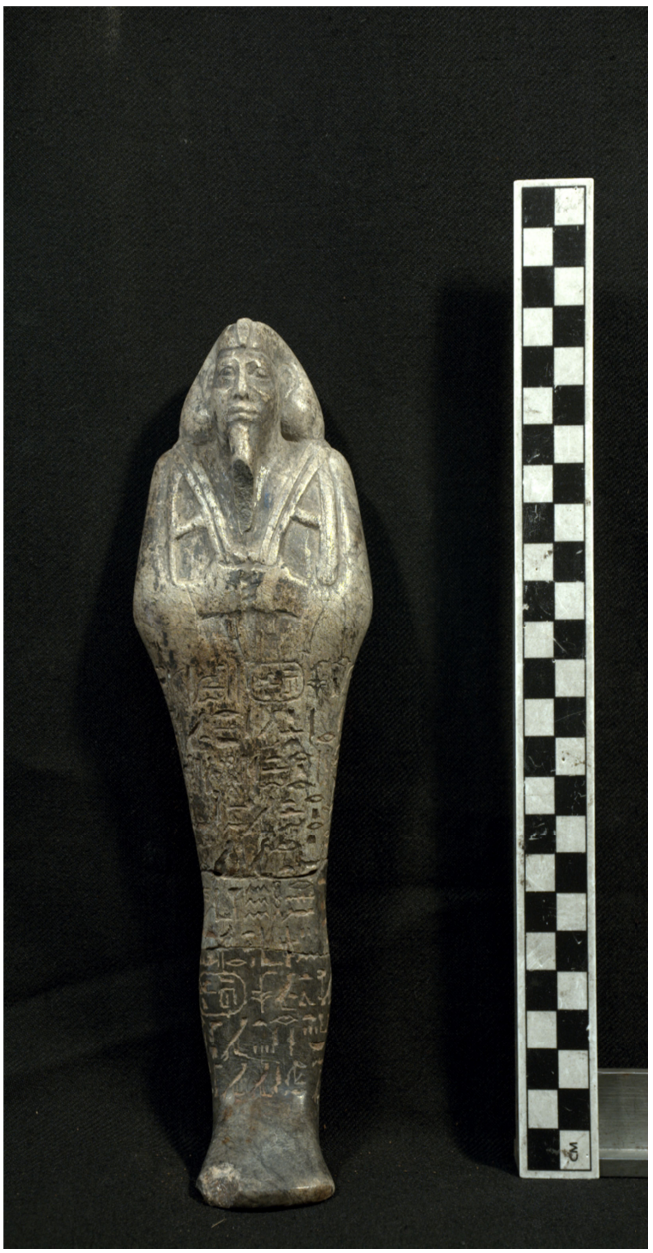

(Fig. 1) The Front Side

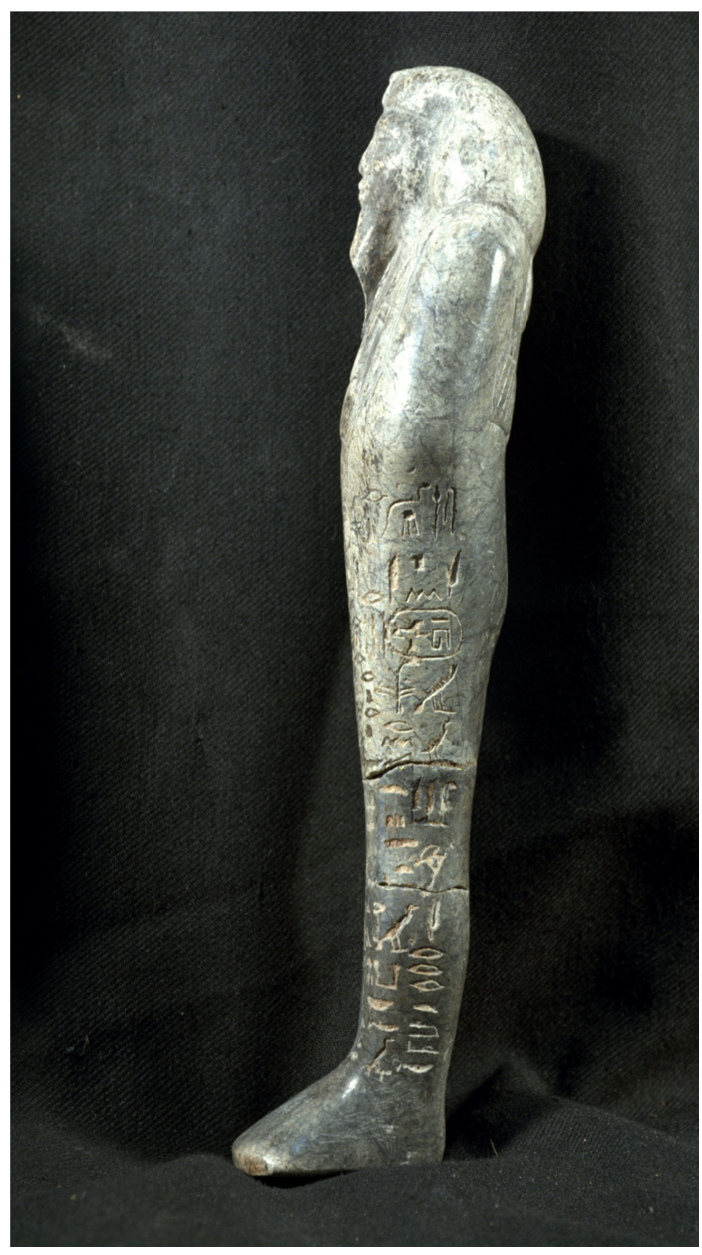

(Fig. 2) The Left Side

(Photo: Sameh Abd Almohsen) 


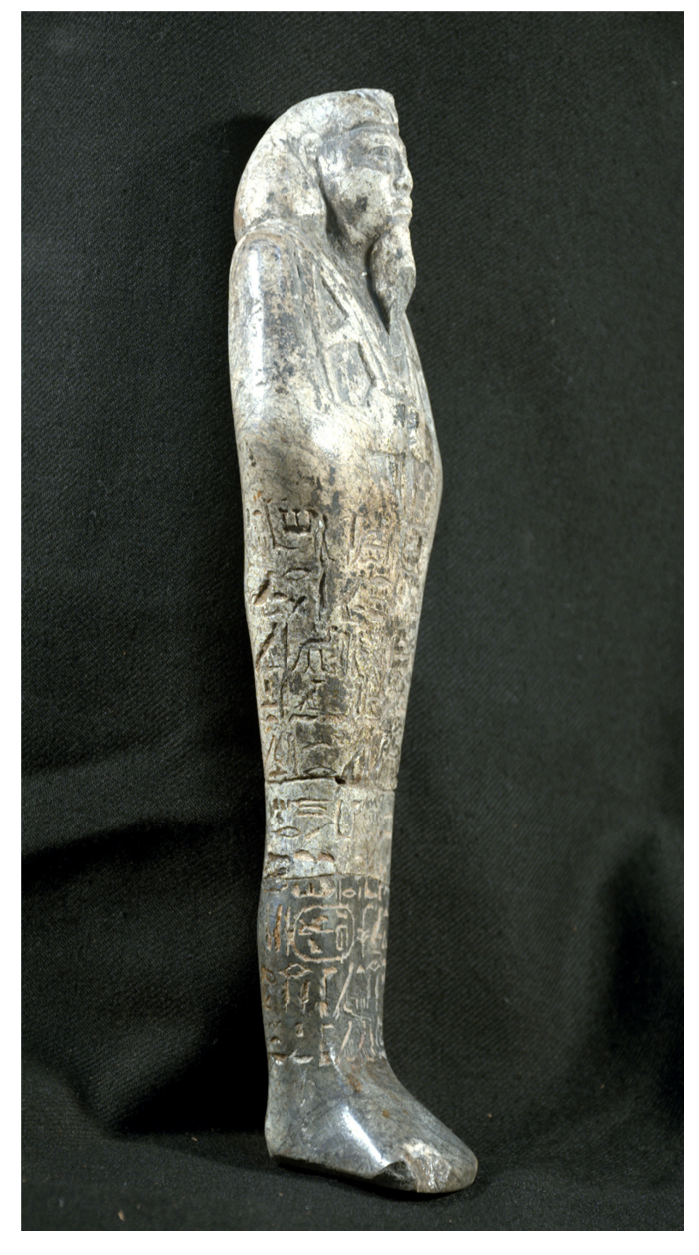

(Fig. 3) The Right Side

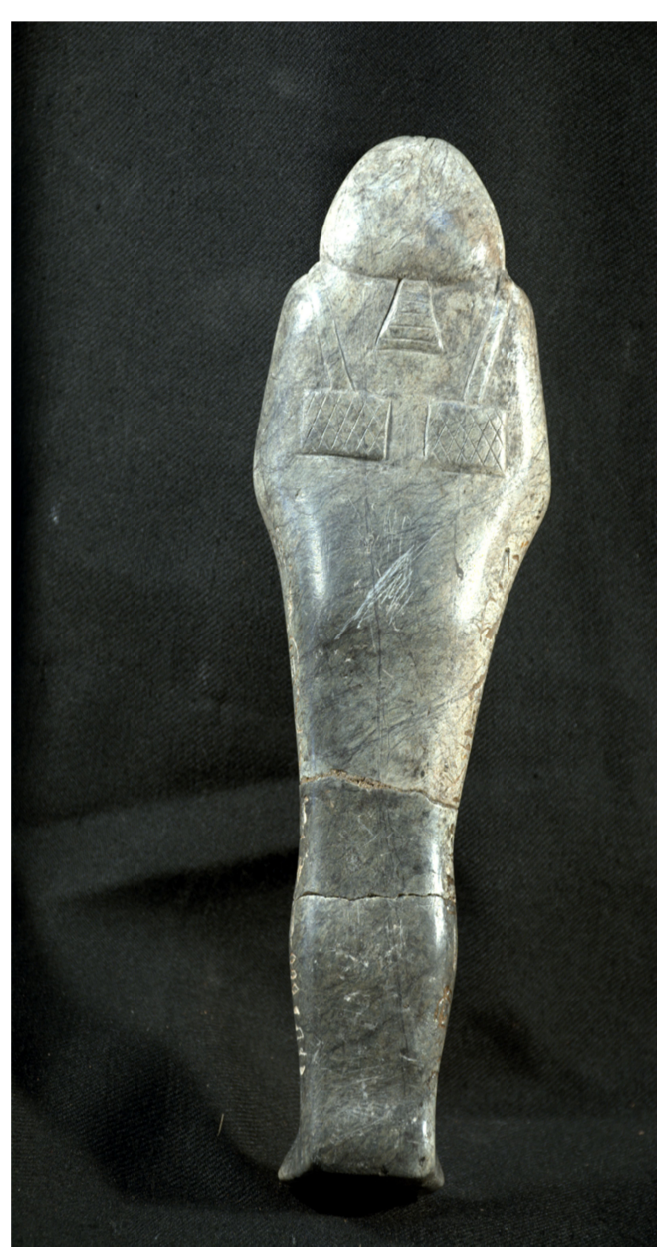

(Fig. 4) The Back Side

(Photo: Sameh Abd Almohsen) 

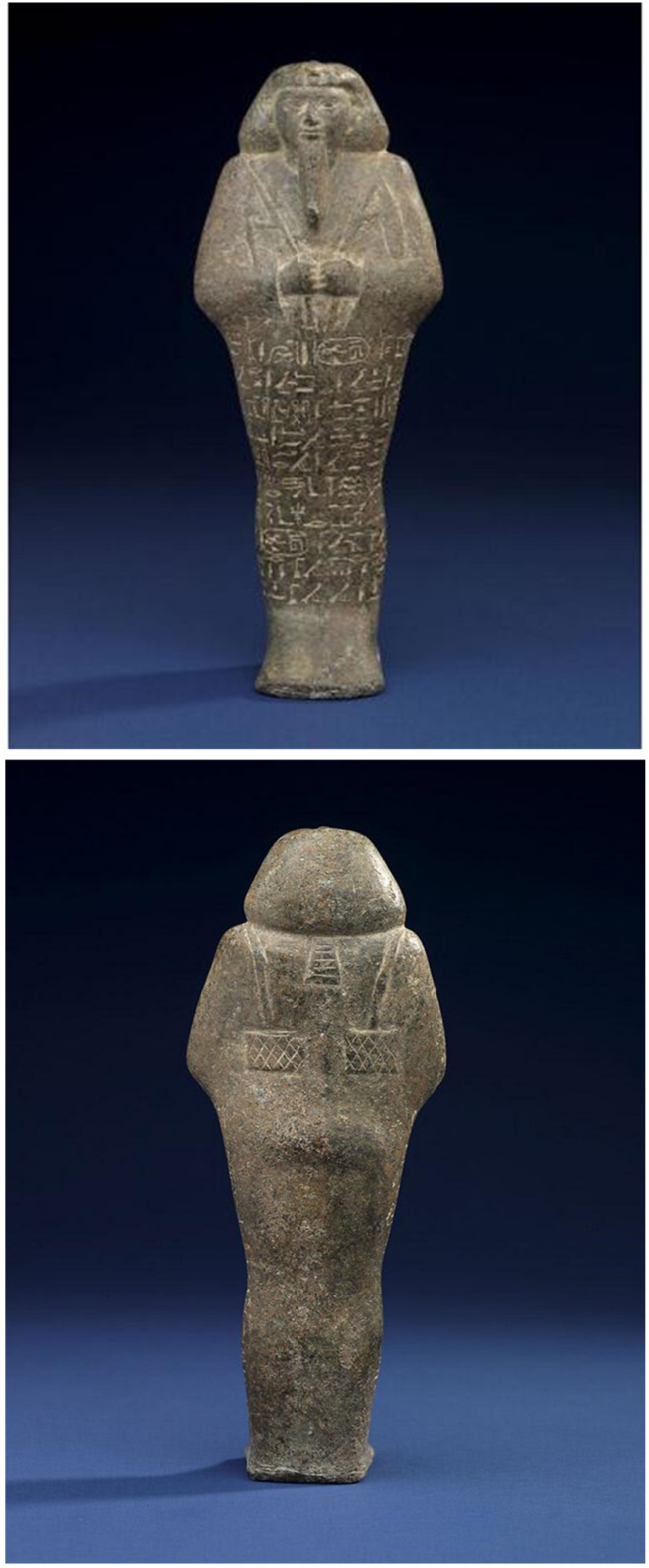

(Fig. 5) Shabti of Taharqa, Royal Ontario Museum, Accession number: 926.15.2 


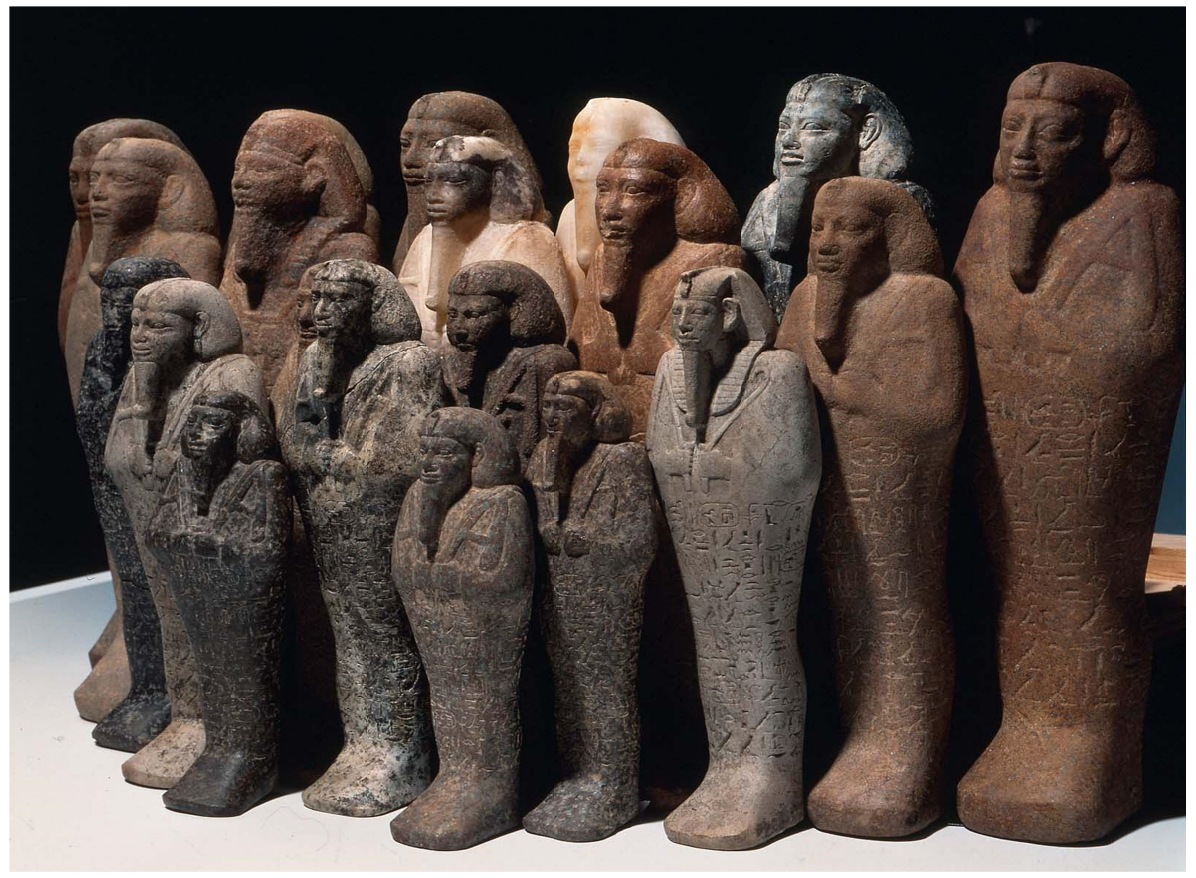

(Fig. 6) Shabti Collection of Taharqa, Boston Museum of Fine Arts, Accession Number: 20.225

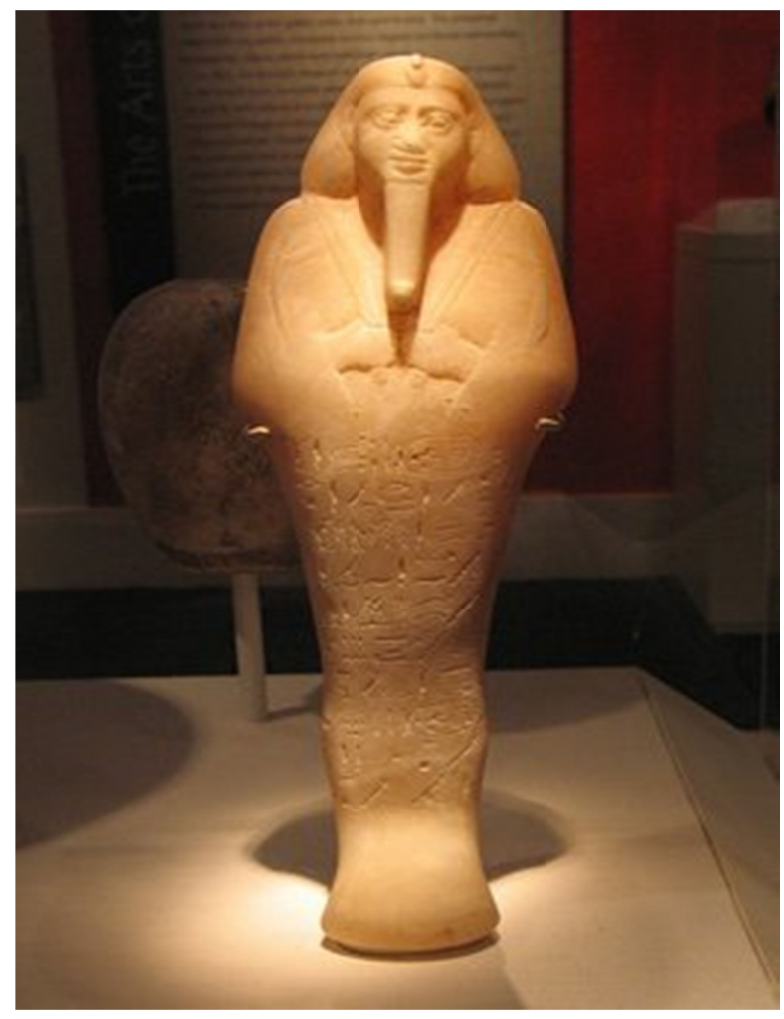

(Fig. 7) Shabti of Taharqa, Brooklyn Museum, Accession Number: 39.4 
(Fig. 8) Shabti of Taharqa, Brooklyn Museum,

Accession Number: 39.2

(Fig. 9) Shabti of Taharqa, Brooklyn Museum,

Accession Number: 39.3

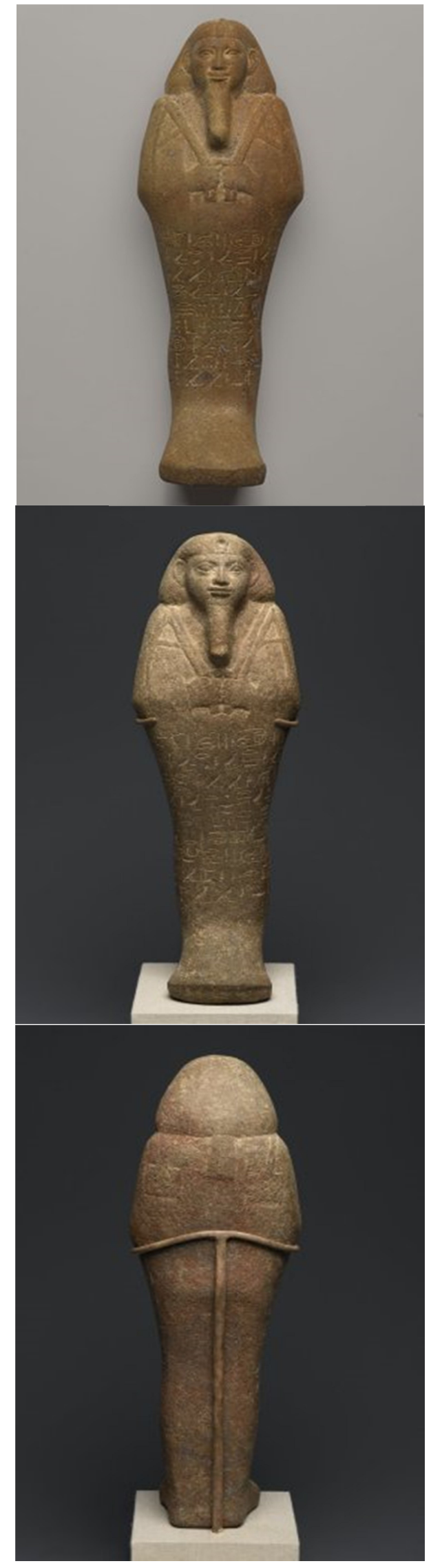




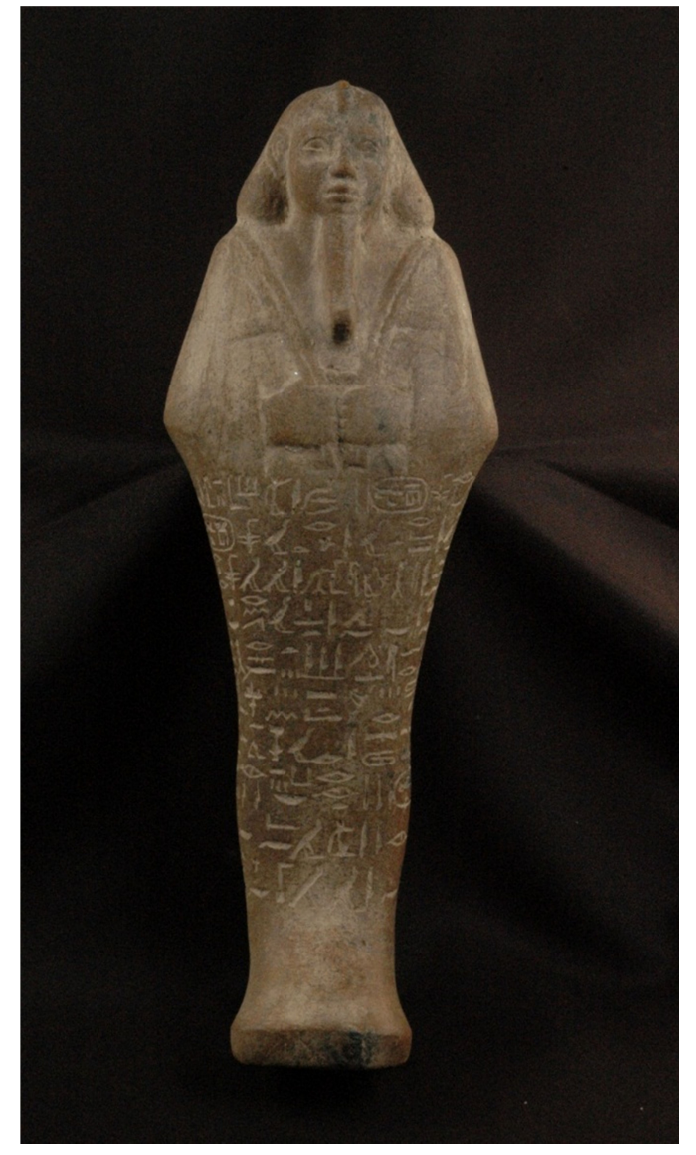

(Fig. 10) Shabti of Taharqa, Egyptian Museum, Accession Number: JE 46506

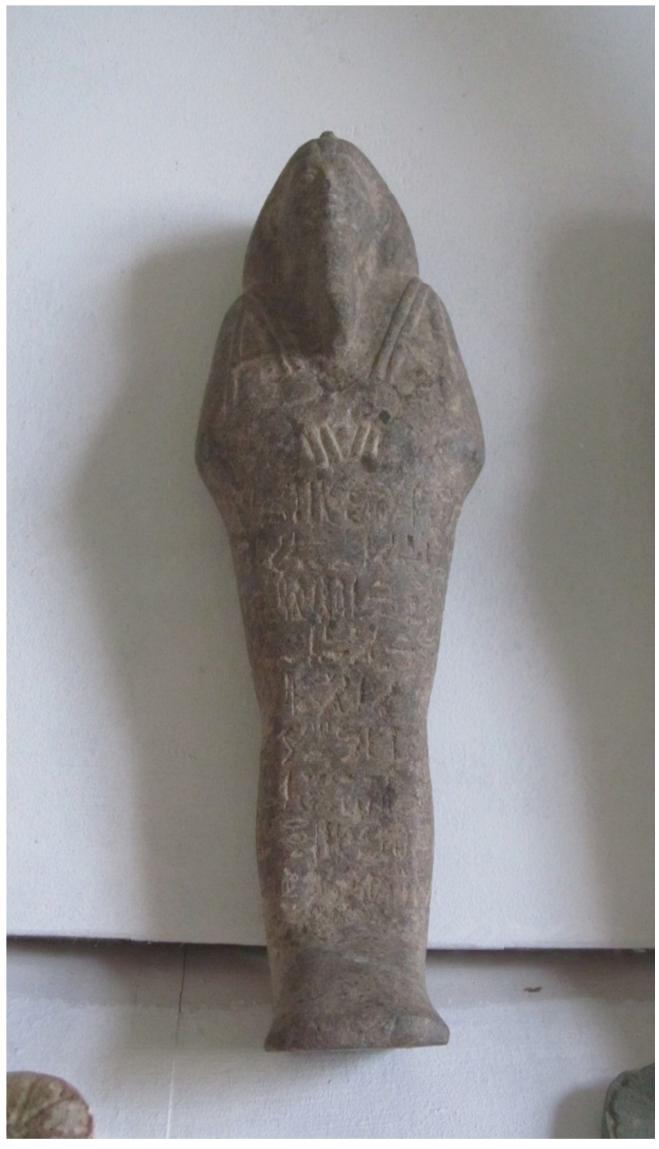

(Fig. 11) Shabti of Taharqa Egyptian Museum Accession Number: JE 46507 


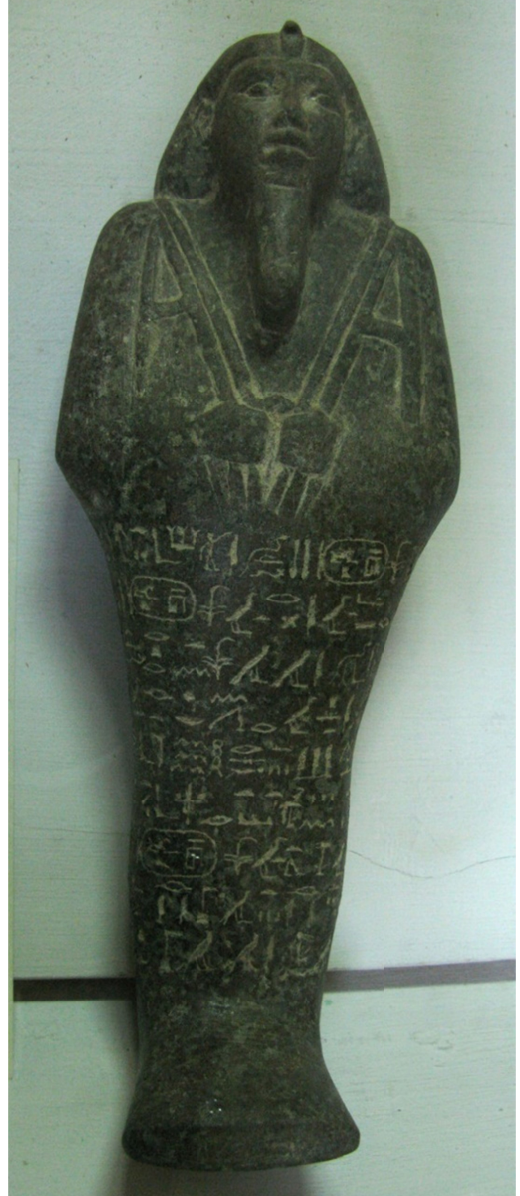

(Fig. 12) Shabti of Taharqa, Egyptian Museum,Accession Number JE 46508

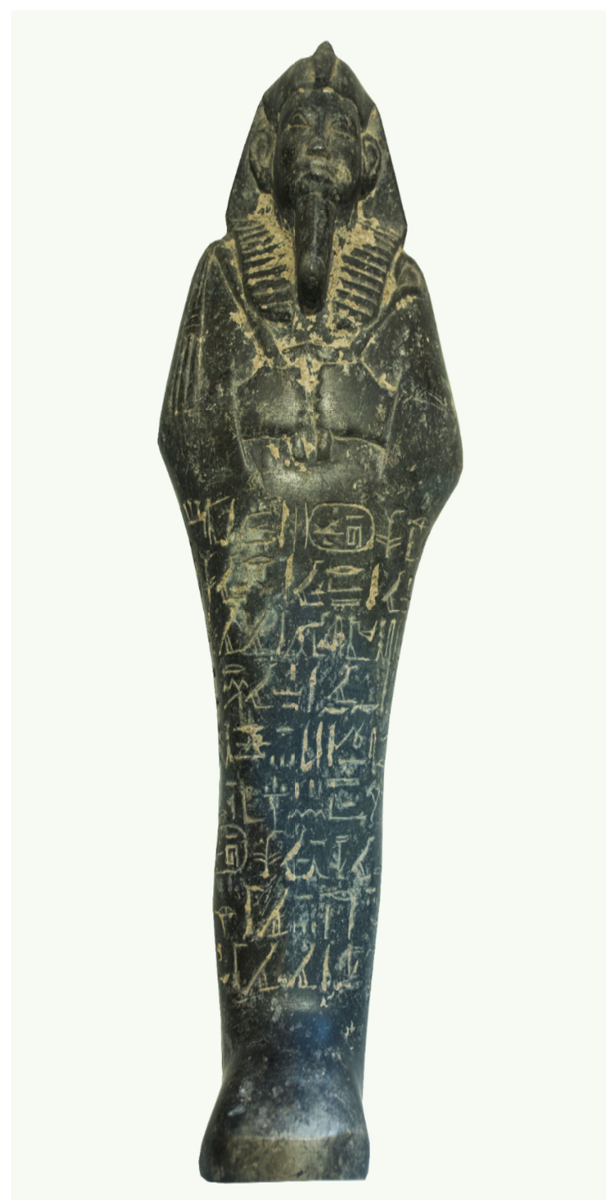

(Fig. 13) Shabti of Taharqa, Egyptian Museum, Accession Number: JE 46509. 